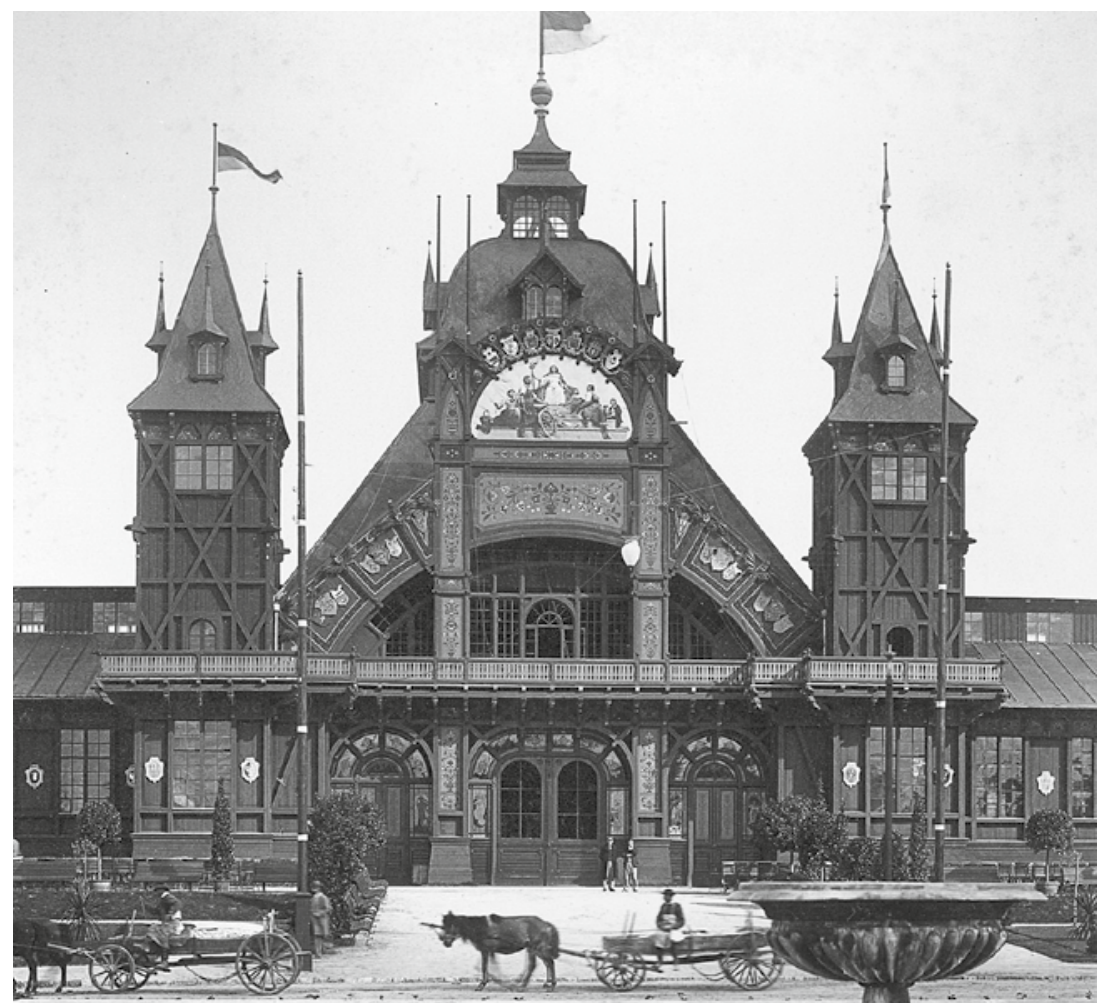

GENERAL REGIONAL EXHIBITION IN LVIV, INDUSTRIAL PALACE, 1894

VŠEOBECNÁ ZEMSKÁ VÝSTAVA VE LVOVĚ, PRŮMYSLOVÝ PALÁC, 1894

Source Zdroj: Archival photo, Lviv Historical Museum

\title{
The Work of Karel Boublík
}

\section{Dílo Karla Boublíka}

\author{
Yury Biryulov
}

https://doi.org/10.31577/archandurb.2021.55.1-2.8

Článek poprvé podrobně zkoumá život a umělecké dílo Karla Boublíka (1869 - 1925), lvovského architekta českého původu. V letech 1897 - 1914 byl autorem mnoha obytných budov ve Lvově. Boublík též vedl Českou besedu ve Lvově - nejstarší český spolek ve světě mimo Česko, byl také amatérským hercem a režisérem. Tvorba Karla Boublíka zaujala na konci 19. a začátkem 20. století významné místo v uměleckém životě Lvova. Nejen pro studium architektury města je proto důležité a naléhavé zkoumat, uchovávat a popularizovat dědictví tohoto umělce. Jeho osobnost a dílo dosud nebyly podrobně prozkoumány v intencích dějin umění a ve své vlasti, České republice, je Boublík mezi odborníky stále neznámý.

Účelem článku je zjistit specifika architektonického dědictví K. Boublíka. Základem studie je komplexní přístup využivající biografické a historicko-kulturní metody a zahrnující uměleckou analýzu. Archivní zdroje a informace z tehdejšího tisku jsou nedílnou součástí studia.

Boublíkovy budovy jsou př́kladem architektury přechodného období od historismu v jeho novobarokní verzi k secesi (art nouveau) a druhé vlny historismu v letech 1909 - 1914 s prvky modernizovaných historických stylů. Jeho budovy byly výjimečné originalitou, se zvláštním důrazem na sochařskou výzdobu a kovové ozdoby. Byla prokázána tendence tohoto architekta zvýraznit vystupující sférické a prizmatické formy, s ostrým vertikálním akcentem střech, často pyramidálních, se složitými zakončeními - s víceúrovňovými zvlněnými a zaoblenými atikami, věžemi a vikýři.

Karel Boublík, lvovský architekt českého původu, se narodil 6. listopadu 1869 v malém městě Kolinci nedaleko Plzně. V roce 1884 začal studovat a v roce 1887 absolvoval stavební a technický obor na Vyšší státní průmyslové škole v Brně. V letech 1889 - 1925 pracoval ve Lvově. 
Od roku 1897 navrhuje Boublík řadu nájemních domů, většinou na objednávku podnikatelů a majitelů domů židovského vyznání. Autor uvažuje urbanisticky, často vytváří bloky několika domů, architektonické celky, pečlivě zvažuje jejich detaily, přičemž zvláštní pozornost věnuje téměř sochařské plasticitě arkýřo̊ a balkonů, včetně dokončení budov - vysoké podkroví, střechy a věže složitých tvarů; zavádí asymetrii fasád kolem centrální osy. Boublík představil jako jeden z prvních lvovských architektů nové principy plánování vnitřní struktury bytového domu. Od tradiční, pro historismus typické enfilády místností podél zadních fasád postupně přechází k plánování obytných sekcí, představuje válcovité šachtice „černého“ schodiště, věnuje pozornost detailům infrastruktury a potřebám obyvatel objektu. Poslední roky 19. století (1897 - 1900) a samotný počátek 20. století (1901 - 1902) jsou nesmírně plodným obdobím Boublíkova díla. Arzenál novobarokních uměleckých prostředků použivá různými způsoby, někdy se obrací k rané secesi, ale vždy zůstává na této hranici, nepřekračuje mez úplného přechodu k modernismu.

Byla odhalena nová fakta ze života a umělecké biografie Karla Boublíka. Je prokázáno, že v letech 1890 - 1914 patřil k předním architektům ve Lvově. Byly analyzovány jeho lvovské budovy, zvláštnosti jejich konstrukce a výzdoby s projevy různých stylistických směrů.

Jeho nejlepší domy, postavené na přelomu 19. a 20. století, dosud tvoří tvář starého Lvova a lze je právem považovat za pýchu města. Vložil rovněž hodně energie do tehdejší činnosti české komunity ve Lvově.

Karel Borromei Vilém Boublík, an architect of Czech origin, was born on 6 November 1869 in the small town of Kolinec, near Pilsen, in the family of a public official (economic adjunct) Matěj Boublík. ${ }^{1}$ In 1884 he began his secondary studies, graduating in 1887 in construction and engineering from the German-language Higher State Industrial School in Brno. ${ }^{2}$ Among the teachers of this school were the famous architects Wilhelm Dwořak and Alois Prastorfer, who designed the building of the school itself, though the young Boublik was most deeply influenced by another of his teachers, Professor Germano Wanderley. In the late 188 os, Wanderly began to turn to the Neo-Baroque style using voluminous shapes, tall windows and towers with domes of capricious contours. Examination of his works, such as the German House in Brno (1887 - 1891, co-founders of Hermann Ende, Wilhelm Böckmann), the villa of Julius Langer (1888 - 189o) and especially the Oswald Ottendorfer Library $(1890-1892)$ in Svitavy, reveals elements that would later become part of the buildings of Karel Boublík.

After graduation, Boublík worked as a designer in Brno (especially with the builder Moritz Käuffler) until 1889, when he decided to move to Lviv, with the help of his uncle, military officer Václav Boublik.

From 1889 to 1890 he worked as a technical and construction sketch artist. In 1890 he married a Czech woman, Zdeňka Šestáková, daughter of the wealthy landowner Josef Šesták (Vtelenský, 1847-1914) in Kryvchytsi (Krzywczyce, a village on the outskirts of Lviv). ${ }^{3}$ From 1890 to 1894 Boublík was an assistant in the Lviv branch of the Vienna firm of Ferdinand Fellner and Hermann Helmer, classics of the Austrian Neo-Baroque, and a designer in the office of Julian Zachariewicz; at the same time, from 1891 to 1897 he worked in the building department of the Municipality. From 1895 to 1896 he was head of the technical office of Ivan Levynsky. In November 1896 Boublík successfully, though not brilliantly, passed the examination at the Galicia (Regional) Office, which was attended by the prominent Lviv architects Sylvester Havryshkevych, Gustaw Bisanz and Michal
Kowalczuk. He received a "good" and a "sufficient" rating for the town hall project for the 500oo-strong city, along with his oral description of the construction process and hygiene conditions. ${ }^{4}$ On 30 October 1897 he received official certification - a licence from the Municipality of Lviv, ${ }^{5}$ which gave him the status of certified architect and he started active independent activities, especially in the housing sector.

In 1897, Boublik became a member of the Professional Society of Lviv Builders; ${ }^{6}$ in April 1900 he was among those elected to the management body of the society. From 1891 he lived at Kochanowskiego (now Kostya Levytskoho) vulitsa 3, between 1901 and 1907 - at Zyblikiewicza (now Ivana Franka) vulitsa 11, Mickiewicza (now Lystopadovoho Chynu) vulitsa (in the former villa of the painter Jan Styka), from 1907 he lived at 5, Kurkowa (now Lysenka) vulitsa; he had his own design office in a Neo-Baroque building on the current Pavla Rymlianyna vulitsa 12.

Since 1890 Boublík was a member of the Czech Conversation Club (Česká beseda) in Lviv, the oldest association of cross-border Czechs, founded in 1867. He was also a permanent member of the Board of Directors and for a time ran the Society Library.7 As of 1900, the Czech Conversation Club rented a room on the second floor of Building No. 7 in the Hausmann arcade (Boublík designed his own object for the association). Boublik was also a talented actor, able to recite poems beautifully and take part in amateur theatre (Ochotnické divadlo) productions of the Club. According to a contemporary description, "his voice is as clear as the ring of an anvil, with a very beautiful beard and a distinctive face resembling a high priest". ${ }^{8}$

In 1900, he played the role of Mayor Tomáš Peřina in Václav Štech's play "Small-Town Tradition" ("Maloměstké tradice"), appeared in two comedies by Jaroslav Vrchlický and in Jaroslav Distl's play "Blue Blood". In 1903, Boublík appeared in Karl Želensky's comedy “The Aunt from Russia”. In January 1906, the Czech Theatre presented the play "The Bagpiper of Strakonice" by Josef Kajetán Tyl in the premises of the Pedagogical Society in Lvov. This time, Boublík served as director and stage designer; 
COMPLEX OF FIVE APARTMENT BUILDINGS FOR ISRAEL SUSLAK AND LAZAR ROHATYN, 1898 - 1899 KOMPLEXPĚTIBYTOVÝCHDOMŮ IZRAELE SUSLAKA A LAZARA ROHATYNA, 1898 - 1899 Photo Foto: Yury Biryulov

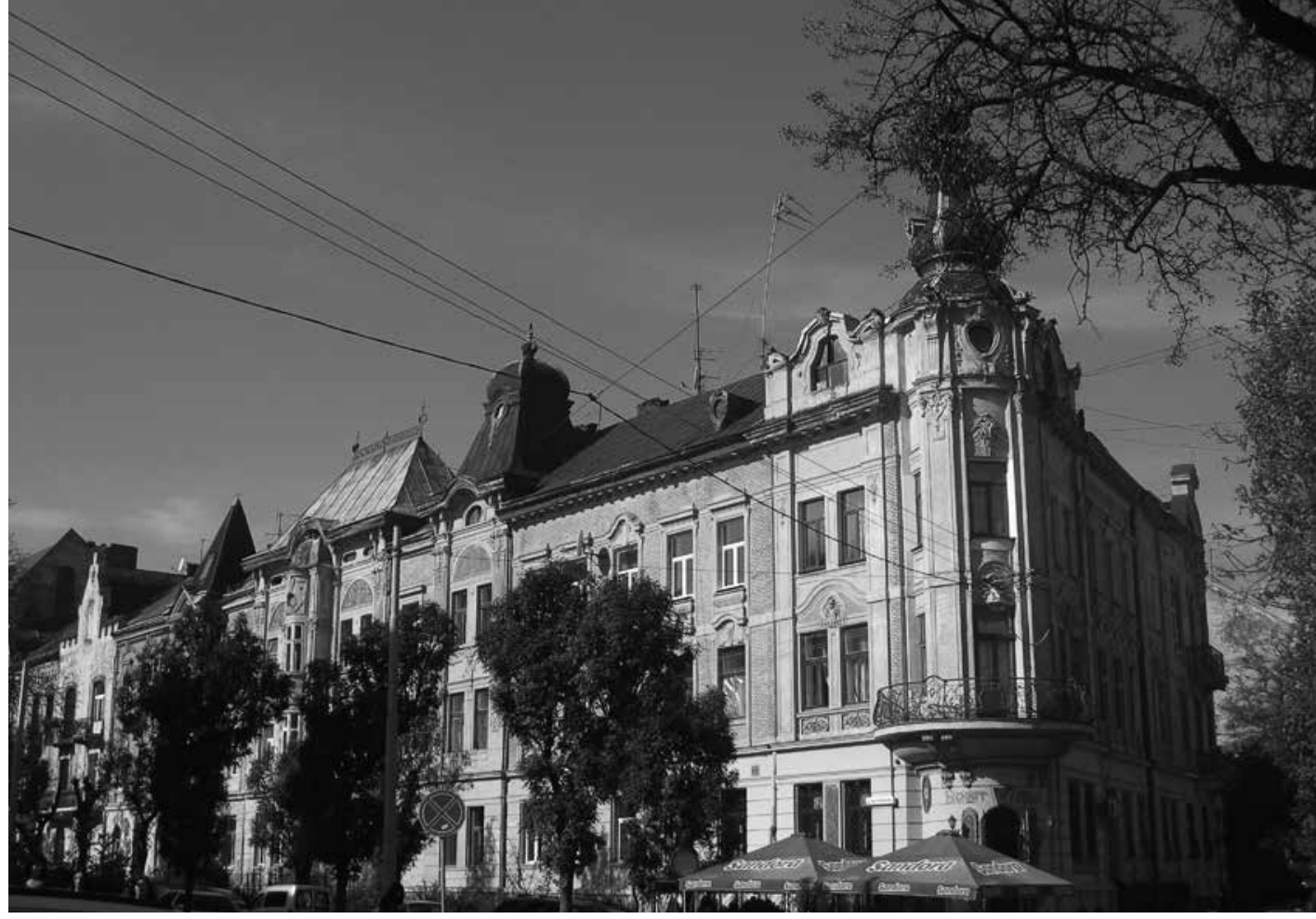

from 1910 to 1914 he directed other amateur performances. In March 1912 he played the role of Stepan Chubukov in the play "A Marriage Proposal" of Anton Chekhov. ${ }^{9}$

Turning to his Lviv architectural work, the present contribution addresses it in chronological order and against the background of the Neo-Baroque orientation that Boublik particularly favoured in the 1890 os, since his time at Fellner and Helmer. During many years of searching in the press and Lviv municipal archives, the author of this article managed to find reliable information about Boublik's works. His drawings (with the author's signatures) in the archives of the former municipal construction department of the City Council in Lviv show that he had an excellent command of architectural graphics, single-handedly completing the projects of facades and floor plans.

His first work in Lviv appeared in 1894, during the General Regional Exhibition. ${ }^{10}$ Boublik obviously knew about the pavilions of the Jubilee Exhibition 1891 in Prague, which was also characterized by a large timbered entrance gate. Then only aged 25, still without authorization for independent building practice, he designed the pavilion of the city of Lviv for this exhibition (co-authored by the more experienced city architect Julian Hochberger). Beautiful and rich ornaments of carved arabesques and a colourful eye-catching roof covered the facade of this pavilion in the style of German Mannerism.

Boublík also supervised the construction of the Industrial Palace, completing the unfinished project of Franciszek Skowron and designing the main facade. ${ }^{11}$ It was the largest building in the exhibition, covering nearly six thousand square meters, with a facade enlivened with an allegorical stained-glass panel by T. Popiel and a Neo-Baroque dome reaching a height of 32 meters. Many industrial products of Galicia enterprises were exhibited here, alongside the separate pavilion of Franz Joseph with statues of knights by Stanisław Wójcik.
Boublík also built a Neo-Baroque concert hall (with a fresco of his own design, realised by the Fleck brothers), ${ }^{12}$ a restaurant, hygiene pavilions and a weaving school in Korczyna. One work that has not survived, indeed planned as an ephemeral structure, was the triumphal arch: to commemorate the arrival of Emperor Franz Joseph to the General Regional Exhibition in September 1894, this arch was constructed on Gródecka (Horodotska) vul., near the railway station; it in fact had been assembled from wood and plaster two years previously in 1892. (Due to fears of a cholera epidemic, the emperor cancelled his planned visit to the capital city of Galicia; in the meantime, the dismantled parts of the gate were stored in the town hall). The architectural conception of the double gate was Boublík's own design; it was fronted on either side by two plaster sculptures: toward Chernivetska vul., a figure "Victoria", by Stanisław-Roman Lewandowski, and, on the opposite side, a statue of the same goddess Victory, in the interpretation of sculptor Anton Popiel. The stucco decoration of the arch (arms, ornamental shields) and large portraits of Franz Josef were created by Peter Harasimowicz. ${ }^{13}$

From 1895 to 1896, when Boublík ran the office of Ivan Levynsky, he probably designed (with the participation of Sylvester Havryshkevych), the "House of Labor" built by I. Levynsky on Sw. Piotra (now Illi Mechnikova) no. 37/39. With workshops and a workers' dining hall, this structure was built in the spirit of "picturesque" historicism, with an emphasis on combinations of coloured bricks, ceramics and wooden details.

Between 1896 and 1898, the architect also designed the two-storey villa of Jan Korzeniowski on Dwernickiego (now Mushaka) no. 46, combining with the Neo-Baroque with a "Swiss" style, with wooden veranda details on the side facade. ${ }^{14}$

The architect's interest in the "Swiss" style and interpretation of elements of Ukrainian and Polish folk architecture was also evident in the design of the wooden buildings of the spa in 


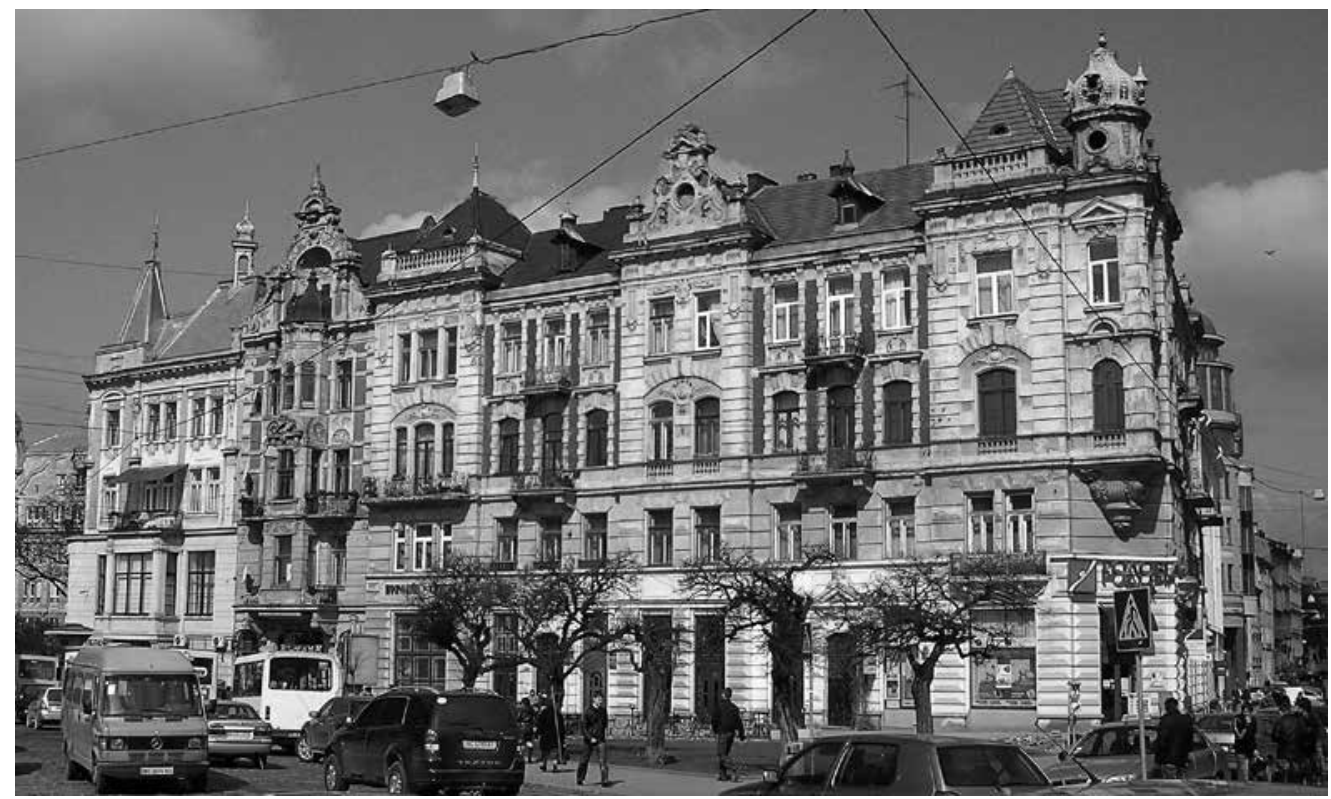

THE JULIUS SPENNADEL HOUSES, 1899- 1902

DOMY JULA SPENNADELA, $1899-1902$

Photo Foto: Yury Biryulov

Janow (now Ivano-Frankove) ${ }^{15}$ in 1896, with a large number of carved structural and ornamental details. ${ }^{16}$

Starting in 1897, Boublík designed a number of rental apartment blocks, mostly commissioned by Jewish entrepreneurs and landlords. The author paid direct attention to their urban planning, often creating blocks of several houses or architectural units, carefully considering the individual details, with a particular eye to the almost sculptural plasticity of bays and balconies, including the completion of buildings - high attic, roofs and towers of complex shapes; introducing asymmetry of facades around the central axis. Additionally, Boublik was one of the first Lviv architects to introduce new principles for planning the interior structure of an apartment building. From the traditional enfilade of rooms along the rear facades, typical of Historicism, the design practice gradually shifted to the planning of residential sections, introducing the cylindrical shaft of the form known as the "black staircase", while devoting new attention to the details of the infrastructure and the needs of the building's inhabitants. The last years of the 19th century $(1897-1900)$ and the very beginning of the 2oth century - 1901 - 1902 formed an extremely fruitful period for Boublík's work. His arsenal of Neo-Baroque artistic means is deployed in various ways, sometimes heading in the direction of early Art Nouveau, but always remains at its margins, never crossing the boundary of a complete transition to Secessionism.

Among these most significant architectural realisations is the complex of five apartment buildings for the entrepreneurs Israel Susliak and Lazar Rohatyn on the corner of Parkova (Pułaskiego) no. 6 - 12 and Rutkovycha (Dombrowskiego) no. $16-18(1898-1899) .{ }^{17}$

A distinctive visual feature of the architectural complex is the semicircular corner composition, complemented by a creative stone tower; these vertical accents continue in the towers of the adjoining blocks, which in turn use helmet-shaped or pyramidal finishes. Considerable attention is paid to the metal details
- balustrades of roofs and balconies (another Czech craftsman, the famous master Jan Dašek (Daschek), was invited to produce them). The sculpted decoration was created by Boublík's longtime collaborator, sculptor Bronisław Sołtys, including masks of female faces, with elements of early Art Nouveau on the facades, Neo-Baroque stucco plafonds and wooden dessus-de-porte in the hall. The Neo-Baroque style also includes picturesque colour decorations - imitation sgraffito with floral ornaments in the curved window pediments of block no. 8 (probably designed by the artist Fryderyk Lachner), or the windowsill with decorative ceramic tiling in block no. 12. On the facade of the same house, there are, apart from the Neo-Baroque, also noticeable Neo-Gothic forms, such as the central bay window on the second floor and in the attic. The facade of the house on Rutkovych vulica 16 is complemented by a semicircular attic with a skylight and a metal spire.

A special addition to this architectural ensemble are the two paired apartment buildings on Rutkovycha vulitsa 10 12, built by Boublík in 1898 for two entrepreneurs, owners of a brickyard and tile factory in Snopkov, Berl Neuwohner and Philip Waldmann. ${ }^{18}$ Their facades, strikingly complemented by semicircular pediments, have a picturesque combination of unplastered two-tone brick masonry with rich Neo-Rococo stucco, concentrated at the level of the upper floors and under the crowning cornice. These are girls' masks, floral garlands, ribbons, cartouches, acanthus leaves and wreaths. Stained-glass windows with vases of flowers etched on the glass are preserved at the top of the door of the main entrance.

During 1898 and 1899, near the ensemble in the streets Pułaskiego and Dombrowskiego, Boublik built a block of houses for Abraham and Mark Polturak at nos. 2 and 4 on Poniatowskiego (now Ulasa Samchuka vulitsa). ${ }^{19}$ Here, we see a successful fixation of the corner of the building thanks to the interplay of protruding geometric shapes, this time not spherical, but prismatic - a triangular loggia with a balcony and a massive tower 
VILLA OF DAVID MAZUR, FACADE DRAWING, 1899

VILA DAVIDA MAZURA, FASÁDNÍ KRESBA, 1899

Source Zdroj: State Archives of Lviv Region

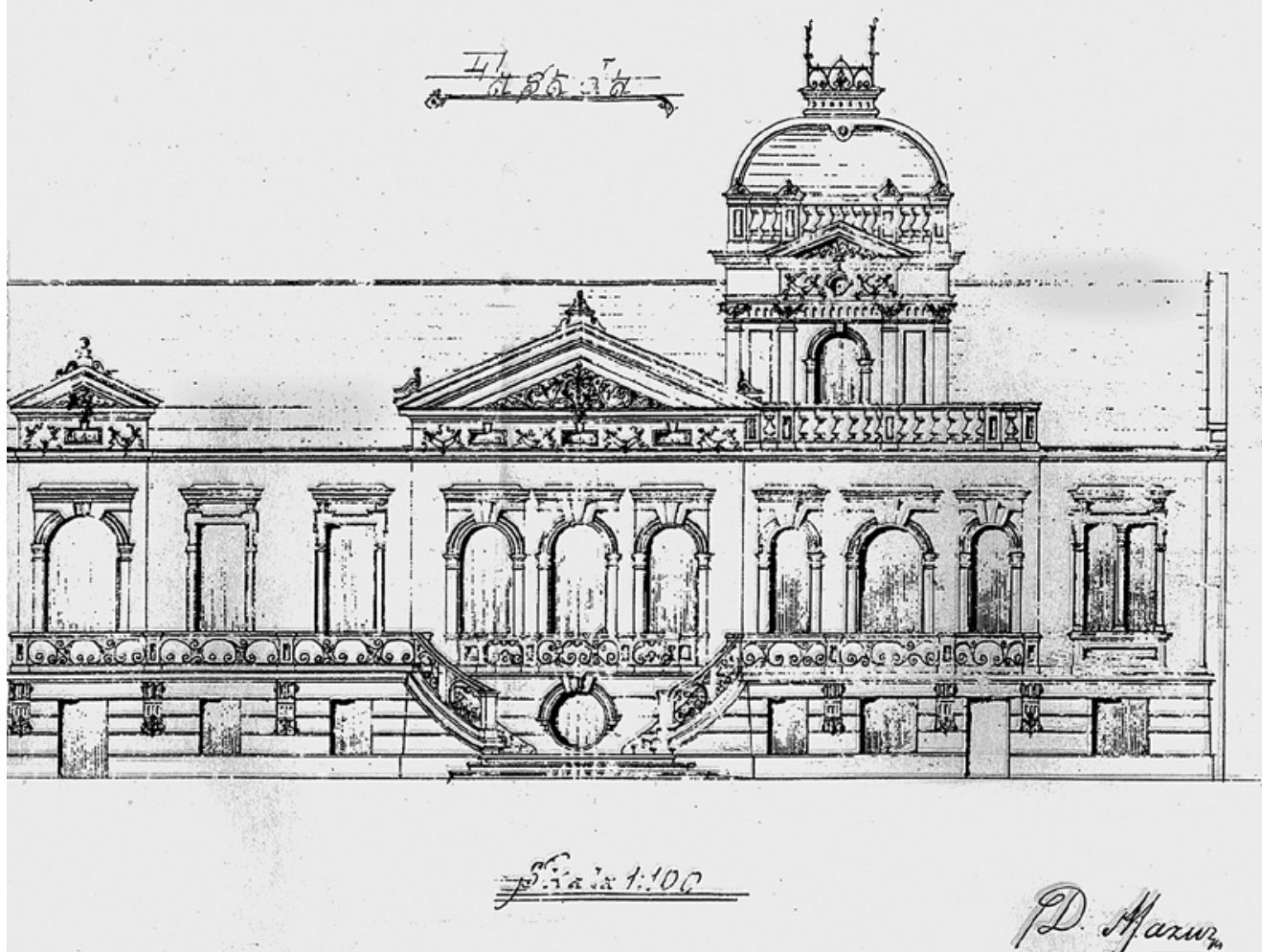

with a pyramidal dome topped by a weathervane. Different colours are skilfully combined - exposed brick, coloured roof tiling, brown ceramic inserts; in the stucco, lion masks are used instead of female ones.

Another excellent ensemble of apartment buildings can be found at the junction of the two squares Halytska and Soborna Halytska ploshcha / Soborna ploshcha (formerly Bernardyński) no. $1-2-2$ a. Here Boublík was active for three years, from the first design projects in 1899 through the start of construction in spring $1901,{ }^{20}$ until their completion in 1902 . These are the apartment buildings for Julius Spennadel, ${ }^{21}$ which came to form an important town planning node, in visual harmony with the Mannerist facade of the ancient Bernardine Church.

The ensemble is perceived differently depending on the point of view: houses with colourful, variegated cladding on the side of Soborna ploshcha impress the viewer with intricate finishes - multi-level undulating and rounded cornices, towers and dormers with pear-shaped cupolas. The facade on the side of Halytska ploshcha was originally crowned with high pyramidal roofs with metal sections and neo-rocaille pediments that have not been preserved. Additionally, the architect's propensity for the steep vertical accents of the roof was previously underscored by the similarly vanished elements of stone obelisks, metal spiers, and weathervanes visible in the archival drawing. The sculptural decor by Bronisław Sołtys, with whimsical animal figures, caryatids and chestnut branches, already displays Art Nouveau features. In designing the spectacular facade of the house at no. 1 on Halytska ploshcha, Edgar Kováts, who also created the interior of the pharmacy "Under the Hungarian Crown" founded in 1772 and owned by Jakub Pipes-Poratyński, paralleled the Neo-Rococo style employed by Boublik. The metal doors of the entrances to all the houses of this complex were made, as evidenced by the signature marks, in the workshop of Jan Dašek. From 1902 to 1934, the "Central" Café was located at Halytska ploshcha no. 7, a gathering place for the poets of the Ukrainian literary association "The Young Muse"; its interior was also decorated by Boublik.

The same architect was also responsible for the interior of the "American" Café with a concert hall, reading room and billiards in the house on the street 3-go Maja (Third of May, i.e. Polish Constitution Day), now Sichovykh Striltsiv (the Sich Riflemen) no. 11. This house, commissioned by Józef Ehrlich ${ }^{22}$ in 1900 - 1901, unfortunately has itself now lost the high stone pediments and towers with metal ornaments so central to the creative spirit of Boublik, that he originally intended in the design of the facade.

However, similar Baroque finishes, pyramidal and conical towers, or hemispherical-domed attics are still preserved on the houses that form the corner of Mykhaila Tuhan-Baranovskoho (formerly Sakramentek), no. $24-26$ and Oleksandra Konyskoho (Ochronek) vulitsa, no. 2/4,constructed in 1899 - 1900 for Feiwel Rohatyn. ${ }^{23}$ The house at the corner of Tuhan-Baranovskoho and Konyskoho 2 was planned as a residential building, and the neighboring one at No. 4 as an administrative one, the latter immediately leased in 1900 by the Military Command of the Galician Division. The facade of the house No. 4 on Konyskoho vulitsa, which now houses the Polish-language Maria Konopnicka School, has arched windows on the third floor against the background of picturesque two-tone brickwork, completed with an attic. 


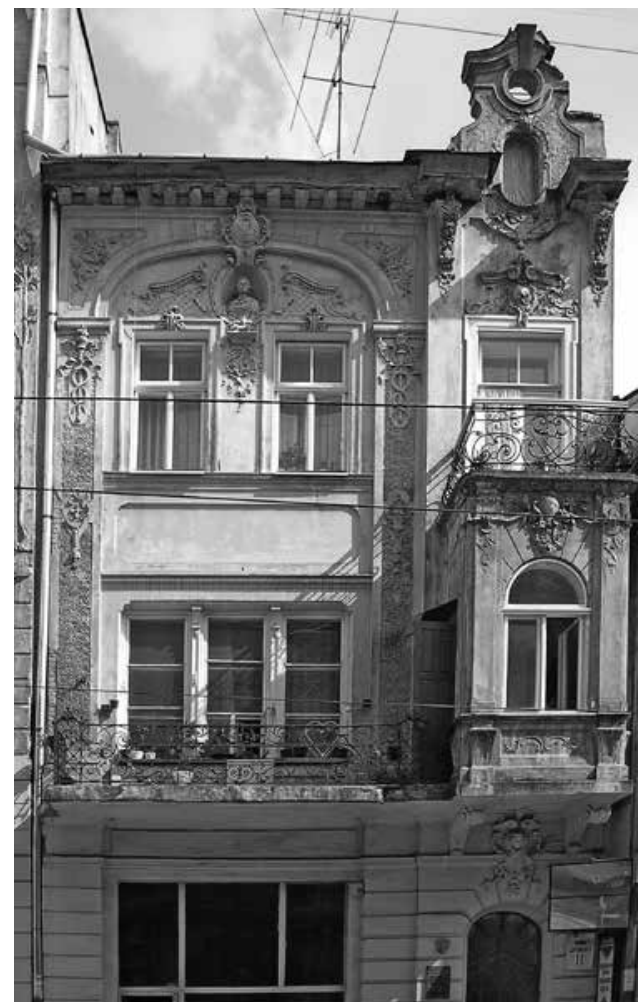

“CHOPIN'S HOUSE", 1898 - 1899

"CHOPINU゚V DŮM", $1898-1899$

Photo Foto: Yury Biryulov

By contrast, the tenement houses erected in $1898-1899$ on the corner of the present Panteleimona Kulisha 1 and Shpytalna (the house of the Burker family, including Benjamin Burker) ${ }^{24}$ and Lychakivska 16 and Witwera vulitsa (the tenement house of Henryk Nitarski) ${ }^{25}$ have flat roofs devoid of high towers and gables. Window pediments, metal and stone balcony railings and sculptural decor are the main artistic expressions here. On the facade of the Nitarski house on the side of Rzeźbiarska Street (today Witwera vulitsa), Sołtys completed a statue of St. Joseph with the infant Jesus.

In $1897-1899$, Boublik built a house at on what is now Saksaganskoho vulitsa, with notable Art Nouveau mascarons of warriors on the facade. However, given the formal and figurative style, we can assume that these are not the works of the late $19^{\text {th }}$-century sculptor Soltys, but instead later decorations of the early 1910 .

Using a pronounced Neo-Baroque style, Boublik in 1899 rebuilt the former villa of the publisher Franciszek Henryk Richter on Pekarska vulitsa no. 11, creating a palace from the studio of the famous Lviv photographer David Mazur (demolished in 1911). ${ }^{26}$

Several residential buildings of Boublik's authorship dating from the late nineteenth century received decorative elements of the early Art Nouveau thanks to the sculptural stucco work of Bronisław Sołtys, in particular, the so-called "Chopin House" on the street Sykstuska (now Doroshenka vulitsa no. 11), built in $1898-1899 .{ }^{27}$ The house of - Sabina and Leon Hescheles, with a musical instrument shop, was decorated with wrought metal by Dašek and sculptures by Sołtys. It boasts a rich Neo-Rococo decor with mascarons, cartouches, images of the lyre, the caduceus of Mercury as a symbol of trade and a bust of Chopin.

In 1898, the construction of two buildings for the entrepreneur Henryk Müller, with the name "Under the Peacock", was completed on the current Ivana Kotliarevskoho vulitsa. ${ }^{28}$ The first of them, at no. 22, is completed at the corner with pediments and a pear-shaped dome and weather vane; on the facade of the second, under No. 24, are imposing sculptures of Sołtys' female heads and a high relief with a peacock figure in an elliptical attic.

From 1903 Boublík, together with Jan Tomasz Kudelski and Anton Rudolf Fleischl, participated in the realization of the Art Nouveau-Neo-baroque Passage Gartenberg in Stanisławów (now Ivano-Frankivsk). The original 1903 project of a shopping arcade by Henrik Gustav Koszic from the firm Fellner and Helmer was completed with works of art; the construction lasted from June to December 1904. Among the monumental paintings in the arcade was a panneaux with a group portrait of architects, including Boublík.

It is not known what caused the pause in his activities between 1905 and 1909. though it can be assumed that, during the culmination of the ornamental Art Nouveau, this architect did not want to obey the prevailing fashion or could not master the new style to match his own expertise. The project of the Rohatyn-Avenue Passage, designed in 1905 on the site of the main building of the Commercial Academy in Lviv (Tuhan-Baranovskoho Street), ${ }^{29}$ was not accepted for realisation by the client.

It was only when in 1908 the mass fascination with the ornamental riot of floral Art Nouveau subsided, and the second wave of Historicism began, already rethought through the prism of Secession, that Boublik became active again. After 1908, his buildings combine transformed images and motifs drawn not only from the Baroque but also the Gothic and Empire.

An ensemble of five apartment buildings on the corner of Shevchenka vulitsa (previouslyJanowska), no. 2 - 4, and Mykoly Leontovycha (Sw. Anna), no. 1 - 7 was completed by Boublik in 1909 - 1910 for the couple Jonah and Gisele Sprecher. ${ }^{30}$ This monumental block forms the urban fabric of the entire city block, and its combination of Baroque and Empire motifs is noticeable in the forms of attics and plastic decorations. The pharmacy "Under St. Anna" in the house at no. 2 opened in 1911. Boublik also made in 1909 a design for a fully Secessionist block at Sw. Anna (Leontovycha), no. 9, which was not realized (construction was entrusted to another architect).

In 1911, following Boublík's project, the house of sculptor Karl (Haskiel) Unz was built on the corner of today's Grabovskoho vulitsa, no. 6 and Lukianovycha no. $2 .^{31}$ Unz himself decorated the facade of this house with statues of atlases and caryatids. A similar combination of retrospective motifs was used by Boublík in 1910 - 1911 in the project of an apartment building with a large domed roof tower at Henerala Tarasa Chuprynky vulitsa, no. 47, It was built as a joint project of Boublík and another Czech-born architect Jaroslav Houžvic. The first design was rendered by Houžvic in the spirit of Viennese geometric Secession, 
but the second design of Boublik was realized in the style of late Historicism. ${ }^{32}$

At the same time, Eva Bilinska's villa appeared on Obwodowa (Ivana Trusha) vulitsa, no. 11 (1911). Originally built in the style of a modernized Baroque, it was recently significantly - and harmfully - modified by the current owners.

Between 1910 and 1912, Boublík built to the order of Maurice and Max Sprecher the "Print House" on the corner of Pidvalna vulitsa no. 3 and Valova no. $31 .{ }^{33}$ After World War I, the house housed the printing and editing offices for the Polish-language Jewish newspaper Chwila ("The Instant"). Boublík combined the Neo-Renaissance attic with other historicist references in the lower parts of the facades, especially elements of the Gothic and Baroque, in the form of windows and balconies and in the stucco decoration.

In 1912, Boublik designed a building for the Polish Sokół (Falcon) gymnastics society in Khodoriv, Lviv region, which was opened on September 1 of that year. ${ }^{34}$ On the pediment, topped with the society's metal emblem, there were stucco Neo-Baroque decorations. ${ }^{35}$ Today this building houses the district department of culture.

In 1912 - 1913, Boublik rebuilt the profitable tenement house of businessman and musician Maurycy Wurm on Hugona Kołłątaja (now Mentsynskoho) vulitsa, no. $3 .^{36}$ The reconstruction made use of the Neo-Baroque style in combination with a modernized Empire idiom, while the decoration of the interior looked toward Art Nouveau. Reconstruction of the facade preserved the authentic dimensions of all structural elements of the first half of the 19th century and its characteristic Empire composition. The ornamental themes of the metal balcony railing fence of a balcony and the stucco moldings and reliefs are typical for the modernized Empire and Baroque, with images of garlands, leaves and wreaths of poppy, acanthus, and grapevines. A fourth attic floor was added, which Boublik separated by a cornice and finished with stylized palmettes.

The house features an interior unique for Lviv inside the stairwell, which is decorated with mosaic panels and artificial marble. A total of 27 mosaics have been preserved on all three floors (two large panels in the lobby were stolen during renovations in 1989). The lower part of the wall is decorated with rhythmically arranged mosaic compositions framed in pink marble, and the gaps between them are lined with beige marble, thus creating rich light and colour effects. The theme of the panel is typical of Art Nouveau: an image of local plant species - pansies, irises, poppies. Each composition is slightly different, the images of flowers are skilfully rendered if somewhat stylized (some panels display more than 30 colour shades). We can assume that this is the work of the Lviv branch of the stained glass and mosaic workshop of Benedikt Škarda in Brno. In 1912, the building's co-owner was Josef Friedländer, who had a similar workshop in Lviv. Other Art Nouveau touches are found in the wrought metal sections of the balustrade, with a motif of calla lillies. This house is the last known work of Boublik.

During the First World War, Boublik remained in Kryvchytsi, where he was engaged in economic affairs. ${ }^{37}$ After the war

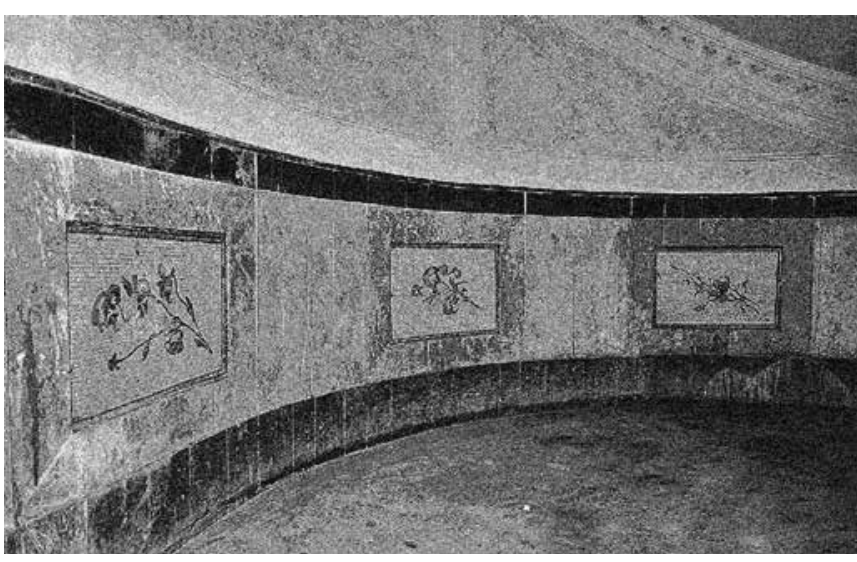

MAURYCY WURM'S HOUSE, STAIRCASE, DETAIL, 1912 - 1913

DŮM MAURYCYHO WURMA, SCHODIŠTĚ, DETAIL, 1912 - 1913 Photo Foto: Yury Biryulov

he did not design any further buildings, only dealing with the affairs of the Czech Conversation Club (Česká beseda). He became the society's chairman starting in 1924, but resigned in January 1925 due to serious illness. His last address, where he lived and where he died - an early Art Nouveau house at A. Gołąba (now Verkhratskoho) vulitsa, no. 15. Boublik died in Lviv on May 1, 1925 at the age of 55 from tuberculosis. ${ }^{8}$ He was buried in Lychakiv Cemetery, but his grave has not survived.

In the architectural environment of Lviv in the late 19th early 2oth centuries, which has been well described in scholarship by such famous researchers as Jacek Purchla,, ${ }^{39}$ Igor Zhuk, ${ }^{40}$ Jakub Lewicki, ${ }^{41}$ Boublik has been identified as a prominent figure who stands out for his bright, individual style of creativity.

In general, his works should be characterized as a typical example of Lviv architecture of the transitional stage - from the Historicism of the late nineteenth century in its Neo-Baroque version to the early Art Nouveau and to the second wave of Historicism of 1909 - 1914, with an appeal to modernized historical styles. His greatest achievements, the apartment blocks built at the turn of the 19th and 2oth centuries, still form the face of Lviv's historic built heritage and can rightly be considered the pride of the city. No less important was the energy that he put into the activities of the Czech community in Lviv at that time.

PROF. YURY BIRYULOV, PH. D. HAB. LVIV NATIONAL ACADEMY OF ARTS 28/39, Trylovskoho str. (vul.) Lviv (Lvov)

Ukraine

yurij.biryulov@gmail.com 
1 Matriční zápisy narozených (Entries in the register of births) 1865-1900, Kolinec kniha 19 Ak fol. 1 - 376, p. 58. In: Porta fontium. Bavorsko-česká sít digitálních historických pramenů [Accessed 04. 06. 2021]. Available at: https://www.portafontium.eu/ iipimage/30063943/kolinec-19_0590$\mathrm{n} ? \mathrm{x}=75 \mathrm{G} \mathrm{y}=27 \mathrm{OG} \mathrm{W}=552 \mathrm{G} \mathrm{h}=193$

2 Jahres-Bericht der k. k. StaatsGewerbeschule in Brünn, 1885 - 1887, 1899.

3 ŠESTÁK, Josef, 1892. Pro český capital (For Czech capital). Národní listy. 32(6), 6. January, p. 7 .

4 SIOMOCHKIN, Igor, 1996. Карел Боублік - чеський архітектор у Львові (Karel Boublik - chesky arkhitektor u Lvovi, Karel Boublík - Czech architect in Lvov). Halyts'ka Brama (The Halich Gate). 3(16), pp. $14-15$.

5 Archive of the Professional Society of Lviv Builders (Archiwum Stowarzyszenia przemysłowego upoważnionych budowniczych we Lwowie), V. Stefanyk Lviv National Library, Manuscripts Department, collection TLB, inventory number 27 , folder 10 , p. 203

6 Stowo Polskie. 1900, 5(174), 13. April, p. 2.

7 TOPINKA, Evžen, 2007. Archiv spolků Česká beseda ve Lvovĕ (1867 - 1936) (Archive of associations Czech Conversation Club in Lviv 1867 - 1936). Lviv: Centre of Europe, p. 130 and more.

8 HOROUTSKÝ, Jan, 1916. Lvovské vzpomínky (II) (Lviv memories II). Jihočeské Listy. 22(61), 2. August, p. 2.

9 Dziennik Polski. 1912, 45(83), 26. March, p. 2.

10 BIRYULOV, Yury, 1994. 100-ліття архітектурного спектаклю (10o-littia arkhitekturnoho spektakliu, 1ooth anniversary of the architectural performance). Halyts'ka Brama (The Halich Gate). 1(2), pp. 8 - 9.

11 Kurjer Lwowski. 1894, 12(159), 10. June, p. 4.

12 Dziennik Polski. 1894, 27(247), 5. September, p. 2.

13 BIRYULOV, Yury. 2015. Львівська скульптура від раннього класицизму до авангардизму (середина XVIII середина XX ст.). (Lvivs'ka skulptura vid rannioho klasytsyzmu do avangardyzmu, Lviv Sculpture from Early Classicism to the Avant-garde (mid 18th to mid 2oth century). Lviv: Apriori, p. 249.

14 State Archives of Lviv Region (SALR), collection (col.) 2: Architectural matters from the archives of the former municipal construction department of the City Council in Lviv, register (reg.) 1, file
4312: The case for the construction of house No. 46 on the Instytutska Dwernickiego, now Mushaka Street, pp. 22, $41-44$.

15 Central State Historical Archives of Ukraine in Lviv, collection (col.) 248: District Directorate of State Railways in Lviv, register (reg.) 2, file 3928, p. 2, $3,18-21$.

16 MERIE, Olga, 2012. Архітектура дерев'яних купалень Східної Галичини XIX - початку XX ст. (Arkhitektura derevianykh kupalen' Skhidnoi Halychyny 19 - pochatku 20 st., Architecture of wooden baths East Galicia 19th - the beginning of the 2oth century). Modern problems of architecture and urbanism. 20 , pp. $91-92$.

17 SALR, col. 2, reg. 1, files 5015, 5017: The case for the construction of houses No. $6-8$ on the Konieva (Parkova) Street, p. 16; file 5019: The case for the construction of houses No. $10-12$ on the Konieva (Parkova) Street, pp. $30-34$; file 5020, pp. 5- 11 .

18 SALR, col. 2, reg. 1, files 5496, 5499: The case for the construction of houses No. $10-12$ on the N. Krupskoi (Rutkovcha) Street.

19 SALR, col. 2, reg. 2, file 2459: The case for the construction of houses No. $2-4$ on the Poniatowskiego (Samchuka) Street, pp. 98 - 101.

20 Przegląd polityczny, społeczny i literacki. 1901, 17(118), 23. May, p. 2.

21 SALR, col. 2, reg. 1, files 1329 1332: The case for the construction of houses No. 1-2 - 2a on Plac Bernardyński; file 2123: The case for the construction of house No. 7 on the Halytski Square.

22 SALR, col. 2, reg. 1, file 1079: The case for the construction of house No. 11 on the September 17 (Sichovykh Striltsiv) Street.

23 SALR, col. 2, reg. 1, file 336: The case for the construction of house No. 2 4 on the D. Biednoho (Konyskoho) Street, pp. $6-12$; reg. 3 , file 870 : The case for the construction of house No. $24-26$ on the Chkalova (TuganBaranovskoho) Street, p. 1, 9.

24 SALR, col. 2, reg. 2, file 4596: The case for the construction of house No. 1 on the Słoneczna (Kulisha) Street.

25 SALR, col. 2, reg. 2, file 235: The case for the construction of house No. 16 on the Lychakivska Street, pp. $67-77$.

26 SALR, col. 2, reg. 2, file 2279: The case for the construction of house No. 11 on the Pekarska Street, pp. $40-42$.
27 SALR, col. 2, reg. 1, file 3731: The case for the construction of house No. 11 on the Zhovtneva (Doroshenka) Street, pp. $80-86,93$.

28 SALR, col. 2, reg. 1, file 5247: The case for the construction of house No. $22-24$ on the Kotliarevskoho Street, pp. 9, $21-29$.

29 GRANKIN, Pavlo, 2010. Будинки Комерційної академії у Львові (Budynky Komertsiynoi akademii $\mathrm{u}$ Lvovi, Buildings of the Commercial Academy in Lviv). In: Grankin, P. Articles (1996 - 2007). Lviv: Centre of Europe, p. 170 .

30 SALR, col. 2, reg. 1, file 4984, pp. $50-57$; files 7111, 7113: The case for the construction of house No. $1-7$ on the Leontovycha Street; reg. 3, file 1110: The case for the construction of house No. $2-4$ on the Shevchenka Street.

31 SALR, col. 2, reg. 1, file 3593: The case for the construction of house No. 6 on the Grabovskoho Street, p. 42.

32 SALR, col. 2, reg. 1, file 3731: The case for the construction of house No. 47 on the Krzyżowa (Henerala Chuprynky) Street.

33 SALR, col. 2, reg. 2, file 2868: The case for the construction of house No. 3 on the Pekarska Street, pp. $1-12$, $51-69,81-89$.

34 Kurjer Lwowski. 1912. 30(363), 9. August, p. 7.

35 Nowości Ilustrowane. 1912, 9(36), 7. September, p. 8.

36 SALR, col. 2, reg. 1, file 6407: The case for the construction of house No. 3 on the Kołłątaja (Mentsynskoho) Street, pp. $52-67,80-88$, file 6408 , pp. $15-25,30$

37 Horoutský, J., 1916, p. 2.

38 Central State Historical Archives of Ukraine in Lviv, col. 618: Roman Catholic Metropolitan Consistory in Lviv, reg. 2, file 2450, pp. 169; Słowo Polskie. 1925, 30(120), 4. May, p. 3, 9; Národní politika. 1925, 43, 5. May, p. 5.

39 PURCHLA, Jacek. 1996. Wpływy wiedeńskie na architekturę Lwowa 1772 - 1918. In: Ostrowski, J. K. (ed.). Sztuka kresów wschodnich. t. 2.. Kraków: Instytut Historii Sztuki, pp. $263-282$; PURCHLA, Jacek (ed.). 1997. Architektura Lwowa XIX wieku. Die Architektur Lembergs im 19. Jahrhundert. Kraków / Krakau: Międzynarodowe Centrum Kultury w Krakowie. 89 p., 174 fig.; PURCHLA, Jacek, 2005. Patterns of Influence: Lviv and Vienna in the Mirror of Architecture. In: Czaplicka, J. (ed.). Lviv: A City in the Crosscurrents of Culture. Cambridge Mass: Harvard University Press, pp. $131-147$
40 ŻUK, Igor. 1991. Architekci secesyjnego Lwowa. In: Grygiel, T. (ed.) Architektura XIX i początku XX wieku. Wrocław - Warszawa - Kraków: Ossolineum, pp. 181 - 188; ZHUK, Ihor. 2005. The Architecture of Lviv from the Thirteenth to the Twentieth Centuries. In: Czaplicka J. (ed.). Lviv: A City in the Crosscurrents of Culture. Cambridge, Mass: Harvard University Press, pp. $95-130$.

41 LEWICKI, Jakub, 2005. Między tradycja a nowoczesnością. Architektura Lwowa lat 1893 - 1918. Warszawa: Neriton. $590 \mathrm{p}$. 